\title{
Veno-arterial extracorporeal membrane oxygenation as a bridge to recovery in a patient with cardiogenic shock due to acute left main coronary artery occlusion
}

\section{Petra Angebrandt*, Marijan Pašalić, Ivo Planinc, Dora Fabijanović, Maja Čikeš, Hrvoje Jurin, Željko Baričević, Jure Samardžić, Davor Miličić, Boško Skorić}

University of Zagreb School of Medicine, University Hospital Centre Zagreb, Zagreb, Croatia

\section{RECEIVED:}

September 15, 2015

ACCEPTED:

September 17, 2015

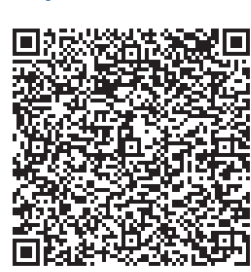

KEYWORDS: heart failure, cardiogenic shock, acute coronary syndrome, extracorporeal membrane oxygenation, left main coronary artery.

CITATION: Cardiol Croat. 2015;10(9-10):233. | DOI: http://dx.doi.org/10.15836/ccar.2015.233

*ADDRESS FOR CORRESPONDENCE: Petra Angebrandt, Klinički bolnički centar Zagreb, Kišpatićeva 12, HR-10000 Zagreb, Croatia. / Phone: +385-7-2367-467 / E-mail: petraang37@yahoo.com

ORCID: Petra Angebrandt, http://orcid.org/0000-0001-5431-9736 • Marijan Pašalić, http://orcid.org/0000-0002-3197-2190 Ivo Planinc, http://orcid.org/0000-0003-0561-6704 • Dora Fabijanović, http://orcid.org/0000-0003-2633-3439 Maja Čikeš, http://orcid.org/0000-0002-4772-5549 • Hrvoje Jurin, http://orcid.org/0000-0002-2599-553X Željko Baričević, http://orcid.org/0000-0002-5420-2324 • Jure Samardžić, http://orcid.org/0000-0002-9346-6402 Davor Miličić, http://orcid.org/0000-0001-9101-1570 • Boško Skorić, http://orcid.org/0000-0001-5979-2346

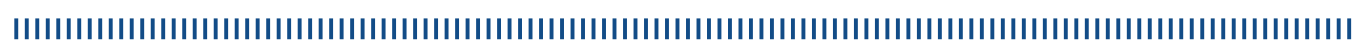

INTRODUCTION: Coronary artery disease represents the most common cause of morbidity and mortality in developed countries. With the introduction of percutaneous coronary interventions (PCI) and the primary PCI network, the mortality of acute myocardial infarction (MI) has significantly decreased. However, patients with acute MI complicated with severe acute heart failure still show poor outcomes. Circulatory support with extracorporeal membrane oxygenation (ECMO) in such patients may serve as either bridge-to-recovery or bridge-to-decision treatment modality. This case highlights the importance of early recognition of the need for ECMO support as well as its early implantation in acute MI complicated with severe acute heart failure. ${ }^{1-3}$

CASE REPORT: A 64-year-old male patient was hospitalized in Coronary Care Unit due to acute anteroseptolateral ST segment elevation myocardial infarction with signs of cardiogenic shock and pulmonary oedema. Echocardiography showed severely reduced systolic function of left ventricle. Inotropic and vasopressor support was initiated. The patient was intubated and mechanically ventilated. Coronary angiogram revealed acute thrombotic occlusion of left main coronary artery (LMCA). Due to the angiography finding and hemodynamic instability, veno-arterial (V-A) ECMO support was introduced, under which a successfull PCI of LMCA was done. Soon after the vessel recanalization, patient became normotensive and both inotropic as well as vasopressor therapy was gradually discontinued. Chronic heart failure therapy was progressively introduced (spironolactone, ACE inhibitor, and finally betablocker). Patient was successfully weaned from ECMO support six days after the implantation, without any complications. Three months later the patient is in NYHA I functional status, with a significant improvement in ECHO finding (LVEF 45\%). Control coronary angiography revealed significant restenosis in the previously implanted BMS and the re-PCI of LMCA with DES and re-PTCA of proximal LAD with DEB was successfully performed under the IVUS control.

CONCLUSION: V-A ECMO is a life-saving therapy in patients treated with PCI in the setting of acute MI complicated with cardiogenic shock. It may serve as a bridge to myocardial recovery, cardiac transplantation or implantation of long-term left ventricular assist device. It is of outmost importance to recognize the need for ECMO support on time, in order to improve the clinical outcome after successful coronary revascularization.

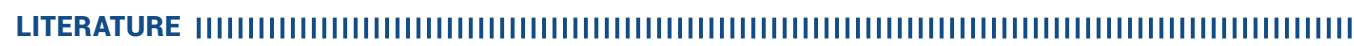

1. Lunz D1, Philipp A, Dolch M, Born F, Zausig YA. [Veno-arterial extracorporeal membrane oxygenation. Indications, limitations and practical implementation]. Anaesthesist. 2014;63(8-9):625-35. DOI: http://dx.doi.org/10.1007/s00101-014-2362-3

2. O'Gara PT, Kushner FG, Ascheim DD, Casey Jr DE, Chung MK, de Lemos JA, et al. 2013 ACCF/AHA guideline for the management of ST-elevation myocardial infarction: a report of the American College of Cardiology Foundation/American Heart Association Task Force on Practice Guidelines. Circulation. 2013;127:e362-e425. DOI: http://dx.doi.org/10.1161/CIR.0b013e3182742cf6

3. Dickstein K, Cohen-Solal A, Filippatos G, McMurray JJ, Ponikowski P, Poole-Wilson PA, et al; ESC Committee for Practice Guidelines (CPG).ESC Guidelines for the diagnosis and treatment of acute and chronic heart failure 2008. The Task Force for the Diagnosis and Treatment of Acute and Chronic Heart Failure 2008 of the European Society of Cardiology. Developed in collaboration with the Heart Failure Association of the ESC (HFA) and endorsed by the European Society of Intensive Care Medicine (ESICM). Eur Heart J. 2008;29(19):2388-442. DOI: http://dx.doi.org/10.1093/eurheartj/ehn309. 